\title{
Vital dye is enough for inguinal sentinel lymph node biopsy in melanoma patients ${ }^{1}$
}

\section{Corante vital é suficiente para biópsia de linfonodo sentinela inguinal em pacientes portadores de melanoma}

\author{
Renato Santos de Oliveira Filho ${ }^{2}$, Allisson Monteiro da Silva ${ }^{3}$, Bernardo Hochman ${ }^{4}$, Renato Leão de Oliveira ${ }^{5}$, Liliana \\ Arcuschin $^{6}$, Jairo Wagner ${ }^{7}$, Lílian Yuri Yamaga ${ }^{8}$, Lydia Masako Ferreira ${ }^{9}$ \\ 1. Work performed in the Research Branch of Plastic Surgery Division of Sao Paulo Federal University - Paulista Medical School \\ (UNIFESP-EPM) - Sao Paulo, Brazil. \\ 2. Affiliated Professor of the Division of Plastic Surgery and Plastic Surgery Post-Graduation Program of UNIFESP-EPM. Coordinator of \\ the Research Branch of Plastic Surgery Division of the Surgery Department of UNIFESP-EPM. Director of Oncology Prevention \\ Center, Sao Paulo, Brazil. \\ 3. Master of Plastic Surgery (UNIFESP-EPM). Physician of Oncology Prevention Center, Sao Paulo, Brazil. \\ 4. Master and PhD fellow in Plastic Surgery Post-Graduation Program of UNIFESP-EPM. Coordinator of the Research Branch of Plastic \\ Surgery Division of the Surgery Department of UNIFESP-EPM. \\ 5. Medical student, colaborator of Oncology Prevention Center, Sao Paulo, Brazil. \\ 6. Physician of Oncology Prevention Center, Sao Paulo, Brazil \\ 7. Director of Nuclear Medicine Service, Albert Einstein Hospital, Sao Paulo, Brazil. \\ 8. Physician of Nuclear Medicine Service, Albert Einstein Hospital, Sao Paulo, Brazil. \\ 9. Full Professor and Head of the Discipline Plastic Surgery Division of the Surgery Department of UNIFESP-EPM and Coordinator of the \\ Plastic Surgery Post-Graduation Program of UNIFESP-EPM.
}

\begin{abstract}
Purpose: The importance of gamma probe detection (GPD) combined with vital dye for sentinel node (SN) biopsy is well accepted. We evaluated the efficacy of patent blue dye (PBD) in identifying inguinal SN. Methods: Ninety-four cutaneous melanoma patients with inferior extremity lesions were submitted to SNB according to a established protocol. Patients were randomized in two groups: Blue group, where SN was identified by PPD and Probe group, where SN was identified by GPD. The median age was 44.2 years and median Breslow thickness was $2.1 \mathrm{~mm}$. Preoperative lymphoscintigraphy, lymphatic mapping with PBD and intra-operative GPD was performed on all patients. Histological examination of SN consisted of hematoxylin-eosin and immunohistochemical staining. If micrometastases were present complete lymphadenectomy was performed. The SN was considered as identified by PBD if it was blue and identified by GPD if it demonstrated at least ten times greater radioactivity than background. Results: It was explored 94 inguinal lymphatic basins, $145 \mathrm{SN}$ were excised (70 guided primarily by blue dye and 75 guided primarily by probe). All SN identified by preoperative lymphoscintigraphy were excised. In the Blue group PPD identified all SN and all of them were hot. In the Probe group all SN were identified by probe and were blue. The coincidence of PPD and GPD was 100\%. Conclusion: Patent blue dye is enough to identify superficial inguinal SN in cutaneous melanoma.
\end{abstract}

Key words: Dyes. Lymphatic Vessels. Probe. Lymph Nodes. Melanoma.

\section{RESUMO}

Objetivo: a importância da detecção gama intra-operatória combinada com corante vital para biópsia de linfonodo sentinela é bem aceita. Nós avaliamos a eficácia do azul patente $V$ na identificação do linfonodo sentinela inguinal.

Métodos: Noventa e quatro pacientes portadores de melanoma cutâneo de membro inferior foram submetidos a biópsia de linfonodo sentinela de acordo com protocolo estabelecido. Foram randomizados em dois grupos: Grupo Azul, onde o linfonodo sentinela foi identificado primariamente com o corante vital azul patente V (Guerbet) e o Grupo Sonda, onde o linfonodo sentinela foi identificado primariamente pela sonda de detecção gama (Neoprobe). A idade mediana foi de 44,2 anos e a espessura mediana de Breslow foi 2,1 mm. Linfocintilografia pré-operatória, mapeamento linfático com azul patente $\mathrm{V}$ e detecção gama intra-opertaória foram realizados em todos os pacientes. O exame histopatológico do linfonodo sentinela consistiu de hematoxilina-eosina e imunohistoquímica. Se micrometástase estivesse presente, linfadenectomia completa era realizada. O linfonodo sentinela era considerado como identificado pelo corante vital se estivesse azul e identificado pela sonda de detecção gama se demonstrasse pelo menos 10 vezes ou mais radioatividade do que o fundo. Resultados: Foram exploradas 94 regiões inguinais, 145 linfonodos sentinelas foram excisados (70 dirigidos primariamente pelo corante vital e 75 dirigidos pela sonda de detecção gama). Todos os linfonodos sentinelas identificados pela linfocintilografia foram excisados. No grupo azul, todos os linfonodos sentinela foram primariamente idenficados pelo corante vital e todos se apresentavam quentes na leitura pela sonda. No grupo sonda, todos os 
linfonodos sentinelas foram primariamente identificados pela sonda e estavam corados pelo azul. A coincidência da sonda com o corante vital foi de $100 \%$. Conclusão: Azul patente V foi suficiente para identificar linfonodo sentinela inguinal em pacientes com melanoma cutâneo.

Descritores: Tintura. Vasos Linfáticos. Sonda. Linfonodos. Melanoma.

\section{Introduction}

Sentinel lymph node (SLN) biopsy has emerged by the end of the $20^{\text {th }}$ Century as a less aggressive procedure to detect micrometastasis. ${ }^{1}$ Only patients with SLN metastasis are submitted to complete lymphadenectomy. Patients without metastasis are preserved, avoiding complications as infection, sensibility disturbances and edema. ${ }^{2}$ This technique has been considered in melanoma and breast cancer staging since 2002 by AJCC / UICC. ${ }^{3,4}$ SLN procedure involves three phases as follows: (1) preoperative lymphoscintigraphy; (2) biopsy of the sentinel node - by means of lymphatic mapping with vital dye and intraoperative gamma probe detection (GPD); (3) histological examination of the node. ${ }^{5}$ Lymphoscintigraphy shows the drainage basins and allows localizing SLN and its projection over the skin. It is essential for this procedure. Lymphatic mapping with vital dye simulates the lymphatic way that tumor cells could have followed from the primary lesion to the SLN. The sentinel node becomes blue. Intra-operative gamma probe detection permits an easy localization of SLN and a less aggressive dissection. ${ }^{6,7}$ The importance of GPD combined with vital dye for SLN biopsy is well accepted. ${ }^{8}$ From 1993 to 1996 we used only lymphatic mapping with PPD for SNB. We observed that inguinal SN was always found when preoperative lymphoscintigraphy showed superficial inguinal SN. The costs of GPD are higher than lymphatic mapping with vital dye. In our country several cancer hospitals don't have gamma probe detection device. So, we proposed to evaluate the efficacy of patent blue dye (PBD) in identifying alone superficial inguinal SN.

\section{Methods}

- Setting - Patients admitted at Oncology Prevention Center - Sao Paulo and treated by a multidisciplinary team (oncology surgeon, nuclear medicine physician and pathologist), from January 1998 to October 2004.

- Patients - Among one hundred and ninety-two melanoma patients submitted to SNB, 94 presented inguinal SN only at preoperative lymphoscintigraphy and formed our study group. All of them signed informed consent. Melanoma primary site was inferior extremity and Breslow thickness was equal to or greater than $0.76 \mathrm{~mm}$ (average $=$ $2.1 \mathrm{~mm}$; range: $0.76-7.0 \mathrm{~mm}$ ). All patients were in vertical growth phase. There were 44 men and 50 women. The average age was 44.2 years (range: 18 - 81 years old).

- Interventions - Patients were alternately allocated in one of two groups: Blue group, where blue dye guided the SNB and Probe group, where probe guided the SNB. If other $\mathrm{SN}$ beyond the inguinal were detected on lymphoscintigraphy, like popliteal or deep pelvic $\mathrm{SN}$, the patient were excluded. To perform preoperative lymphoscintigrapy a quantity of $1 \mathrm{mCi}\left(\mathrm{Tc}^{99 \mathrm{~m}}\right.$ - dextran 500) in a $1 \mathrm{ml}$ volume of $0.9 \%$ normal saline was injected intradermally in equal parts into four quadrants around the biopsy scar or the melanoma lesion if still present. Immediately afterwards, dynamic images were obtained to visualize the lymphatic drainage. Anterior and lateral static images, using a dual-head gamma camera (Eucint Helix HR) were obtained until the SLN was found. The last image was obtained after 2 hours when whole body visualization was done. These images were complemented by oblique views whenever the injection site could obscure the SLN. The position of the SLN was then marked on the skin. PBD was performed in all patients according to the technique described by Morton et al. ${ }^{9}$ Blue group - A $5 \mathrm{~cm}$ inguinal incision was made over the $\mathrm{SN}$ skin point projection determined by preoperative lymphoscintigraphy. Subcutaneous tissue was dissected, identifying a bluestained lymphatic channel. The lymphatic channel was carefully dissected down to the blue-stained SN (Figure 1).

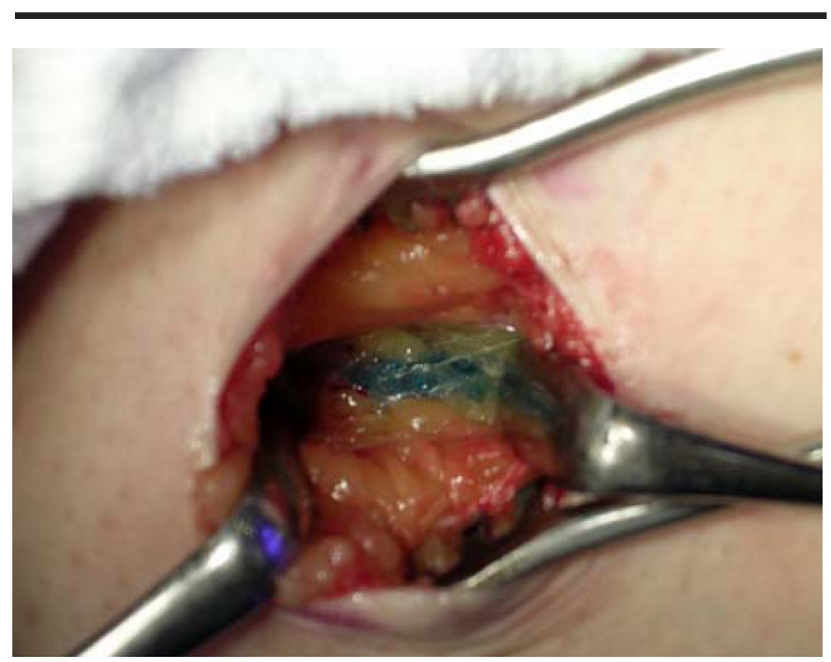

FIGURE 1 - Inguinal sentinel node blue stained.

After excised, the radioactivity of the blue SN was checked by probe.

- Probe group - A $3 \mathrm{~cm}$ incision was done over the hottest point determined by intra-operative gamma probe (Columbus, OH). The hottest node was excised and checked if it was or not blue stained. The operative field was checked looking for another SLN (radioactivity more than $10 \%$ of the hottest ex vivo SLN).

The specimen was sent for pathological examination, using a paraffin hematoxylin-eosin section and immunohistochemical staining (S-100 and HMB-45). Only when micrometastases were present a formal regional lymph node dissection was performed. The average follow-up was 40 months. 
- Main measurement - The SN was considered as identified by PBD if it was blue-stained and by GPD if it was at least ten times more radioactive than background. No special statistic methods were needed.

\section{Results}

PBD and GPD were used in all patients. In blue group (47 patients), the inguinal SN was retrieved only by PPD, all SN identified by preoperative lymphoscintigraphy were blue (70 SN, 1.5 per lymphatic basin). When examined ex vivo by probe, all the $70 \mathrm{SN}$ were hot (at least 10 times more radioactive than background). In probe group, the inguinal SN was retrieved only by GPD, $75 \mathrm{SN}$ were excised (1.6 per lymphatic basin). All SN were blue stained. Micrometastasis was found in 20 patients $(21 \%), 16$ on permanent sections and 4 on immunohistochemistry only. Regional node dissection was performed in 19 patients with micrometastatic SN. In two patients were found positive non sentinel node. Four patients with a tumor - negative SN recurred: 2 recurred in the same basin, 1 developed in-transit metastasis and the other had liver metastasis. Median follow up of the 94 patients was 20 month. All of these recurrent patients had Breslow thickness equal or more than $2.2 \mathrm{~mm}$. Postoperative complications after SLN were seen in six patients which were solved easily (wound infection, hematoma and seroma).

\section{Discussion}

The pathological status of SN is the most important prognostic factor for melanoma recurrence. Sentinel node procedure appears to be a reliable method for regional microstaging of melanoma patients with clinically hidden lymph node metastases. ${ }^{10,11}$ According our data, micrometastasis was found in $21.0 \%$ (20/94 patients). Six patients with negative $\mathrm{SN}$ recurred. Among 19 patients that were submitted to complete lymph node dissection due to positive SN, five $(13,5 \%)$ had another positive node. Factors that could predict the sentinel node status would be useful for counseling patients about treatment options and possible outcomes. Tumor thickness and ulceration of primary lesion are considered dominant independent predictors of sentinel node metastasis. ${ }^{12}$ Some authors have been suggesting Breslow thickness, the amount of tumor and interdigitating dendritic cells into the $\mathrm{SN}$ as prognostic factors for non sentinel nodes status in melanoma patients. ${ }^{13}$ Literature has registered a lower identification rate when using PPD alone than GPD for SNB (85\%). ${ }^{14}$ When both PBD and GPD procedures are combined success rate in localizing SN is optimized (99-100\%). ${ }^{15}$ In our study, PPD identified all inguinal sentinel node when used alone and all inguinal sentinel node was hot. By the other hand, in GPD group, all inguinal sentinel node were identified by probe and were blue stained. So, blue dye showed to be enough for identifying superficial inguinal SN in inferior extremity melanoma patients. Otherwise, probe facilitated the procedure allowing a smaller incision. Previous study had suggested similar results. ${ }^{16}$ Lymphoscintigraphy has a crucial role in localizing the $\mathrm{SN}$ basin and allowing skin localization of the SN. In case of inguinal sentinel node, deep pelvic and popliteal $\mathrm{SN}$ has to be checked by lymphoscintigraphy. It is known that learning curve for SNB using lymphatic mapping with vital dye is longer than that one using probe and that probe increases the costs. For selected patients (inferior extremity cutaneous melanoma) with superficial inguinal SN evidenced by preoperative lymphoscintigraphy), PBD can securely be used alone, improving the cost / benefit relationship of SNB procedure, increasing the number of hospitals where it could be done.

\section{Conclusion}

Patent blue dye is enough to identify superficial inguinal $\mathrm{SN}$ in cutaneous melanoma.

\section{References}

1. Cabanas RM. An approach for the treatment of penile carcinoma. Cancer.1977;39:456-66.

2. Cochran AJ, Binder S, Remotti F. The role of microscopic evaluation in the management of cutaneous melanoma. Cancer Treat Res. 1993;65:69-102.

3. Balch CM, Buzaid AC, Soong SJ, Atinks MB, Cascinelli M, Coit DG. Final version of the American Joint Committee on cancer staging System for cutaneous melanoma. J Clin Oncol. 2001;19(16):3635-48.

4. Schwartz GF, Giuliano AE, Veronesi U. Consensus Conference Committee: proceedings of the consensus conference on the role of sentinel lymph node biopsy in carcinoma of the breast. Cancer. 2002; 94(10):2542-51.

5. Reintgen D, Balch CM, Kirkwood J, Ross M. Recent advances in the care of the patient with malignant melanoma. Ann Surg. 1997;225:1-14.

6. Krag DN, Meijer SJ, Weaver DL, Loggie BW, Harlow SP, Tanabe KK. Minimal access surgery for staging of malignant melanoma. Arch Surg.1995;130:654-8.

7. Gershenwald JE, Thompson W, Mansfield PF, Lee JE, Colome MI, Tseng CH. Multi-institutional melanoma lymphatic mapping experience: the prognostic value of sentinel lymph node status in 612 stage I or II melanoma patients. J Clin Oncol. 1999;17:976-83.

8. Kapteijn BA, Nieweg OE, Liem I, Mooi WJ, Balm AJ, Muller SH. Localizing the sentinel node in cutaneous melanoma: gamma probe detection versus blue dye. An Surg Oncol. 1997;4:156-60.

9. Morton DL, Wen DR, Wong JH, Economou JS, Cagle LA, Storm FK, et al. Technical details of intraoperative lymphatic mapping for early-stage melanoma. Arch Surg 1992;127:392-9.

10. Bostick P, Essner R, Glass E, Kelley M, Sarantou T, Foshag LJ. Comparison of blue dye and probe-assisted intraoperative lymphatic mapping in melanoma to identify sentinel nodes in 100 lymphatic basins. Arch Surg. 1999;134:43-9.

11. Leong SP, Steinmetz I, Habib FA, McMillan A, Gans JZ, Allen Jr RE. Optimal selective lymph node dissection in primary malignant melanoma. Arch Surg. 1997;132:666-72.

12. Lafreniere R. What's new in general surgery: surgical oncology. J Am Coll Surg. 2004;198(6):966-88. 
13. Cochran AJ, Wen DR, Huang RR, Wang HJ, Elashoff R, Morton DL. Prediction of metastatic melanoma in nonsentinel nodes and clinical outcome based on the primary melanoma and the sentinel node. Mod Pathol. 2004; 17:747-55.

14. Morton DL, Thompson JF, Essner R, Elashoff R, Stern $\mathrm{SL}$, Nieweg OE. Validation of the accuracy of intraoperative lymphatic mapping and sentinel lymphadenectomy for early stage melanoma: a multicenter trial. Ann Surg. 1999;230:453-5.
15. Mariani G, Erba P, Manca G, Villa G, Gipponi M, Boni G. Radioguided sentinel lymph node biopsy in patients with malignant cutaneous melanoma: the nuclear medicine contribution. J Surg Oncol. 2004;85(3):141-51.

16. Oliveira Filho RS, Santos ID, Ferreira LM, de Almeida FA, Enokihara MMSS, Barbieri A, Tovo Filho R. Is intraoperative gamma probe detection really necessary for inguinal sentinel lymph node biopsy? São Paulo Med J. 2000;118(6):165-8.

\section{Correspondence:}

Renato Santos de Oliveira Filho

São Paulo Federal University

Division of Plastic Surgery / Department of Surgery

Rua Napoleão de Barros, $715 / 4^{\circ}$ andar

04024-900 São Paulo - SP - Brazil

Phone: (55 11)5576-4118

renato.dcir@unifesp.epm.br
Conflict of interest: none Financial source: none

Received: September 03, 2005

Review: October 13, 2005

Accepted: November 08, 2005

\section{How to cite this article:}

Oliveira Filho RS, Silva AM, Hochman B, Oliveira RL, Arcuschin L, Wagner J, Yamaga LY, Ferreira LM. Vital dye is enough for inguinal sentinel lymph node biopsy in melanoma patients. Acta Cir Bras [serial on the Internet] 2006 Jan-Feb;21(1). Available from URL: http://www.scielo.br/acb

*Color figure available from www.scielo.br/acb

\section{AVISO AOS AUTORES}

Solicita-se aos autores observarem o estilo e as Normas da Revista Acta Cirúrrgica Brasileira.

Consultar os artigos publicados em fascículos recentes da revista.

Acessar http://www.scielo.br/acb - Instruções aos autores.

Informações adicionais pelo e-mail: sgolden@terra.com.br 